\title{
PENGARUH RASIO-RASIO RISK-BASED BANK RATING (RBBR) TERHADAP PERINGKAT OBLIGASI
}

\author{
(Studi Empiris: Obligasi Perbankan yang Terdaftar \\ pada Bursa Efek Indonesia Tahun 2009-2013) \\ Agita Putra Pramana ${ }^{1}$ dan Irni Yunita ${ }^{2}$ \\ Program Studi Manajemen Bisnis Telekomunikasi dan Informatika, \\ Universitas Telkom \\ irniyunita81@yahoo.com
}

\begin{abstract}
ABSTRAK
Peringkat obligasi merupakan salah satu indikator ketepatan waktu pembayaran pokok dan bunga utang obligasi. Selain itu, peringkat obligasi mencerminkan skala risiko dari semua obligasi yang diperdagangkan. Dengan demikian semakin tinggi peringkat obligasi, semakin menunjukkan bahwa obligasi tersebut terhindar dari risiko default. Namun hingga saat ini tidak ada keterangan yang jelas bagaimana lembaga pemeringkat memperingkatkan obligasi. Sebagai investor perlu mengetahui faktor - faktor apa saja yang mempengaruhi peringkat obligasi, sehingga investor tahu pasti keadaan perusahaan sebelum memutuskan melakukan investasi.
\end{abstract}

Risk-based bank rating (RBBR) menggantikan analisis CAMEL dalam menilai kesehatan perbankan. Sedangkan telah diketahui bahwa analisis CAMEL tidak hanya dapat digunakan untuk menilai kesehatan bank namun dapat juga digunakan sebagai indikator dalam menyusun peringkat dan memprediksi kebangkrutan bank. Demikian pula dengan RBBR, cakupan penilaian yang digunakan RBBR meliputi faktor Profil Risiko (risk profile), Good Corporate Governance (GCG), Rentabilitas (earnings), dan Permodalan (capital). Jika dihubungkan dengan peringkat obligasi, RBBR memiliki kesamaan dalam pengukuran kinerja perusahaan melalui rasio-rasio keuangan yang digunakan.

Penelitian ini bertujuan untuk menguji apakah terdapat pengaruh rasio-rasio yang digunakan pada RBBR terhadap peringkat obligasi. Rasio yang menjadi variabel dari penelitian ini adalah NPL, LDR, BOPO, ROA, NIM, dan CAR. Serta melibatkan delapan bank yang terdafar di Bursa Efek Indonesia untuk dijadikan sampel dalam penelitian berdasarkan purposive sampling. Metode analisis data yang digunakan adalah regresi data panel selama periode tahun 20092013.

Hasil dari penelitian menunjukkan bahwa terdapat pengaruh rasio-rasio RBBR secara simultan terhadap peringkat obligasi dan hanya rasio NPL yang berpengaruh secara parsial terhadap peringkat obligasi sedangkan rasio LDR, BOPO, ROA, NIM, dan CAR tidak berpengaruh secara parsial terhadap peringkat obligasi. Pada rasio-rasio yang digunakan dalam penelitian menunjukkan bahwa rasio tersebut dapat menjelaskan peringkat obligasi sebesar 95,57\%. sedangkan sisanya 4,43\% dijelaskan oleh rasio lain di luar penelitian.

Keywords: Peringkat Obligasi, Risk-based bank rating (RBBR), Non Performing Loan (NPL), Loan to Deposit Ratio (LDR), Biaya Operasional terhadap Pendapatan Operasional (BOPO), Return On Asset (ROA), Net Interest Margin (NIM), Capital Adequacy Ratio (CAR) 


\section{PENDAHULUAN}

JURNAL

MANAJEMEN

INDONESIA

Vol. 15 - No. 1

April 2015
Pertumbuhan obligasi korporasi di Indonesia ada tahun 2013 meningkat 26,9 persen di kuartal pertama. Pertumbuhan ini merupakan yang tertinggi di Asia, disusul dengan Cina yang tumbuh 25,3 persen. Tingginya pertumbuhan obligasi di Indonesia didorong oleh meningkatnya kebutuhan pendanaan korporat untuk ekspansi usaha dan pembayaran utang jatuh tempo. Asia Development Bank mencatat pertumbuhan obligasi korporasi bulan maret 2013 didominasi oleh sektor perbankan dan institusi finansial (tempo.co, 5 juni 2013). Menurut Bodie et al., (2010) obligasi lebih dipilih investor karena obligasi lebih mudah dimengerti karena besarnya pembayaran sudah ditentukan dari awal dan risiko yang ditanggung relatif lebih kecil selama penerbit obligasi dapat dipercaya kemampuannya untuk membayar hutangnya. Ditambah pendapat Haryanti (Sejati, 2010) bahwa perkembangan obligasi yang pesat ini antara lain dikarenakan rendahnya tingkat suku bunga Sertifikat Bank Indonesia (SBI) dan tingkat suku bunga deposito sehingga investor lebih tertarik untuk menanamkan modalnya pada obligasi. Sedangkan menurut Faerber (Setyapurnama, 2008) jika dibandingkan dengan saham, investor lebih memilih berinvestasi pada obligasi karena dua alasan, yaitu: (1) volatilitas saham lebih tinggi dibanding obligasi, sehingga mengurangi daya tarik investasi pada saham, dan (2) obligasi menawarkan tingkat pengembalian yang positif dengan pendapatan tetap (fixed income), sehingga obligasi lebih memberikan jaminan dibanding saham. Dengan demikian investasi obligasi sangat cocok bagi investor yang senang terhadap investasi yang aman dan minim risiko.

Menurut Sejati (2010) setiap investor selalu mengharapkan suatu hasil atau keuntungan dari kegiatan investasi yang dilakukannya. Namun, dalam dunia investasi selalu terdapat kemungkinan dimana harapan investor tidak sesuai dengan kenyataan, atau selalu terdapat risiko. Investor yang menanamkan dana di pasar obligasi harus mewaspadai adanya risiko perusahaan penerbit obligasi tidak mampu memenuhi janji yang telah ditentukan, yaitu risiko perusahaan tidak mampu membayar kupon maupun mengembalikan pokok obligasi (risiko default atau risiko gagal bayar). Agar investor memiliki gambaran tingkat risiko ketidakmampuan perusahaan dalam membayar, maka didalam dunia surat hutang atau obligasi dikenal suatu tingkat yang menggambarkan kemampuan bayar perusahaan penerbit obligasi. Tingkat kemampuan membayar kewajiban tersebut dikenal dengan istilah peringkat obligasi. Pernyataan tersebut diperkuat dengan pendapat Altman (Raharja dan Sari, 2008) peringkat obligasi sangat penting bagi investor karena mampu memberikan pernyataan informatif dan memberikan sinyal tentang kemungkinan kegagalan utang suatu perusahaan.

Di Indonesia memiliki beberapa lembaga pemeringkat obligasi, namun perusahaan-perusahaan yang terdaftar di Bursa Efek Indonesia lebih banyak menggunakan jasa PT. Pemeringkat Efek Indonesia (PEFINDO) dibanding dengan agen jasa pemeringkat lainnya. Disisi lain ada beberapa kasus yang terjadi saat ini sehingga dapat menimbulkan suatu pertanyaan apakah peringkat obligasi yang dinilai oleh agen pemeringkat di Indonesia tersebut memiliki gambaran tentang kinerja perusahaan yang sebenarnya. Salah satunya terjadi kasus pada Bank Global di tahun 2004 yang menyatakan bahwa peringkat obligasi yang dikeluarkan pemeringkat Kasnic adalah A-. Selang beberapa saat Bank Indonesia mengumumkan izin Bank Global dibekukan kemudian peringkat obligasinya turun menjadi D (default). Dengan ini dapat diketahui pemeringkatan yang dilakukan oleh agen pemeringkat Kasnic menjadi bias atau tidak mencerminkan keadaan perusahaan sesungguhnya. 
Menurut Chan dan Jegadeesh (2004), salah satu alasan mengapa peringkat obligasi yang dikeluarkan oleh agen pemeringkat tersebut tidak sesuai dengan kondisi sebenarnya karena agen pemeringkat tidak melakukan pengawasan terhadap kinerja perusahaan setiap hari dan agen pemeringkat hanya menilai dari terjadinya suatu peristiwa saja. Selain itu tidak terdapat kejelasan lebih lanjut dari agen pemeringkat bagaimana laporan keuangan dan faktor-faktor lainnya dapat digunakan dalam menentukan peringkat obligasi. Untuk itu investor perlu mengetahui faktor - faktor apa saja yang mempengaruhi peringkat obligasi, sehingga investor tahu pasti keadaan perusahaan sebelum memutuskan melakukan investasi. Menurut Foster (Linandarini, 2010) berpendapat bahwa faktor yang dapat dipertimbangkan agen pemeringkat dalam menentukan pemeringkat suatu obligasi diantaranya berbagai rasio keuangan, provisi indentiture agreements, perlindungan terhadap aset yang ada dan kualitas manajemen. Namun didalam perusahaan perbankan memiliki karakteristik yang berbeda dengan perusahaan manufaktur dalam pemeringkatkan obligasi. Pada agen pemeringkat PEFINDO sendiri terdapat dua motode yang digunakan untuk menilai peringkat obligasi antara perusahaan yang tergolong perusahaan finansial seperti perbankan dengan perusahaan manufaktur.

Dalam menilai kinerja perbankan erat kaitannya dengan penilaian kesehatan yang dilakukan oleh Bank Indonesia pada bank umum yang ada di Indonesia. Melalui Peraturan Bank Indonesia Nomor 6/10/PBI tahun 2004 untuk menilai tingkat kesehatan bank umum di Indonesia maka digunakan analisis CAMEL yang terdiri dari aspek Capital, Assets, Management, Earnings dan Liquidity. Menurut Payamta dan Machfoedz (Dewi, 2010) CAMEL tidak sekedar mengukur tingkat kesehatan bank, tetapi juga digunakan sebagai indikator dalam menyusun peringkat dan memprediksi kebangkrutan bank. Namun pada tahun 2011 diberlakukan peraturan baru yang menggantikan CAMEL sebagai metode analisis kesehatan bank. Melalui Peraturan Bank Indonesia Nomor 13/1/PBI/2011 bank wajib melakukan penilaian tingkat kesehatan dengan menggunakan pendekatan risiko (Risk-based Bank Rating). Riskbased Bank Rating yang selanjutnya disingkat RBBR mencakup aspek profil risiko (risk profile), good corporate governance (GCG), rentabilitas (earnings), dan permodalan (capital).

Pada prinsipnya RBBR memiliki kesamaaan dengan CAMEL, namun RBBR memiliki cakupan analisis yang lebih luas. RBBR banyak membahas risiko-risiko inheren dan kualitas penerapan risiko dalam operasional serta aspek GCG yang berjalan pada perusahaan perbankan. Indikator-indikator yang ada pada RBBR seperti risiko, rentabilitas dan permodalan diukur secara kuantitif melalui rasio-rasio keuangan sedangkan GCG diukur secara kualitatif melalui pertanyaan-pertanyaan yang harus dijawab manajemen perbankan. Namun dalam penelitian ini semua indikator yang terkandung dalam RBBR akan dihubungkan atau diproksikan pada rasio-rasio keuangan unuk memprediksi peringkat obligasi. Menurut Chen (Wilopo, 2001) rasio keuangan bermanfaat dalam menilai kondisi kesehatan perbankan, memprediksi kelangsungan usaha baik yang sehat maupun yang tidak sehat. Rasiorasio keuangan yang digunakan dan dijadikan proksi dari indikator-indikator RBBR adalah Non Performing Loan (NPL) dan Loan to Deposits Ratio (LDR) merupakan proksi dari risiko, Beban Operasional Pendapatan Operasional (BOPO) merupakan proksi dari GCG, Return on Assets (ROA) dan Net Interest Margin (NIM) merupakan proksi dari rentabilitas, dan Capital Adequacy Ratio (CAR) proksi dari permodalan. Rasio-rasio tersebut digunakan berdasarkan standar pengukuran kesehatan yang berlaku pada Peraturan Bank Indonesia Nomor 13/1/PBI/2011.
JURNAL

MANAJEMEN

INDONESIA

Vol. 15 - No. 1

April 2015 


\section{LANDASAN TEORI}

JURNAL

MANAJEMEN

INDONESIA

Vol. 15 - No. 1

April 2015

\subsection{Obligasi}

Menurut Sulistyastuti (Arif, 2011) yang dimaksud dengan obligasi (bond) adalah sekuritas berpendapatan tetap (fixed income securities) yang diterbitkan sehubungan dengan perjanjian utang. Dalam melakukan pembelian obligasi, investor di pasar modal itu sendiri bisa mendapatkan keuntungan, yakni mendapatkan tingkat suku bunga (kupon), selain itu bisa menghasilkan pendapatan atas kenaikan nilai nominal obligasi ke harga premium tersebut di pasar sekunder. Terdapat empat ketentuan yang menjadi daya tarik obligasi:

1. Emiten membayar bunga dalam jumlah tertentu yang dibayar secara regular.

2. Emiten akan membayar kembali pinjaman tersebut dengan tepat waktu.

3. Obligasi mempunyai jatuh tempo yang telah ditentukan ketika obligasi habis masanya dan pinjaman harus dibayar penuh pada nilai nominal.

4. Tingkat bunga kompetitif, dapat dibandingkan dengan keuntungan yang didapat investor dari tempat lain.

\subsection{RBBR Sebagai Indikator Peringkat Obligasi}

Pada awal tahun 2012 diberlakukan peraturan bagi seluruh bank umum di Indonesia melalui Peraturan Bank Indonesia Nomor 13/1/PBI/2011 tentang Penilaian Tingkat Kesehatan Bank Umum, setiap bank diwajibkan untuk melakukan penilaian sendiri (self assessment) terhadap Tingkat Kesehatan Bank dengan menggunakan pendekatan risiko (Risk-based Bank Rating/RBBR) baik secara individual maupun secara konsolidasi, dengan cakupan penilaian meliputi faktor Profil Risiko (risk profile), Good Corporate Governance (GCG), Rentabilitas (earnings), dan Permodalan (capital) untuk menghasilkan Peringkat Komposit Tingkat Kesehatan Bank. Kemudian keempat aspek tersebut akan diproksikan dengan rasio-rasio keuangan. Sehingga dengan menganalisis rasio keuangan dapat diperoleh gambaran baik buruknya keadaan atau kinerja keuangan suatu bank. Indikator-indikator RBBR beserta rasio yang digunakan dijelaskan sebagai berikut:

1. Profil Risiko (Risk Profile)

Penilaian faktor Profil Risiko merupakan penilaian terhadap risiko inheren dan kualitas penerapan Manajemen Risiko dalam aktivitas operasional Bank. Pada aspek ini diukur dengan menggunakan rasio Non Performing Loan (NPL) dan Loan to Deposit Ratio (LDR).

Rasio NPL digunakan untuk menunjukan kemampuan manajemen bank dalam mengelola kredit bermasalah yang diberikan oleh bank. Bank dalam memberikan kredit harus melakukan analisis terhadap kemampuan debitur untuk membayar kembali kewajibannya. Apabila kondisi NPL suatu bank tinggi maka akan memperbesar biaya baik biaya pencadangan aktiva produktif maupun biaya lainnya sehingga berpotensi terhadap kerugian bank. Semakin tinggi rasio ini maka akan semakin buruk kualitas kredit bank yang menyebabkan jumlah kredit bermasalah semakin besar maka kemungkinan suatu bank dalam kondisi bermasalah semakin besar. Kredit dalam hal ini adalah kredit yang diberikan kepada pihak ketiga tidak termasuk kredit kepada bank lain. Kredit bermasalah adalah kredit dengan kualitas kurang lancar, diragukan dan macet (Dewi, 2010). Rasio ini dapat dirumuskan sebagai berikut: 
No. Performing Loan (NPL) $=\frac{\text { Kredit Bermasalah }}{\text { Total Kredit }} \times 100 \%$

Sumber: Bank Indonesia

JURNAL

MANAJEMEN

INDONESIA

Rasio LDR digunakan untuk menunjukkan kemampuan bank untuk memenuhi kemungkinan ditariknya deposito/simpanan oleh deposan/penitip dana ataupun memenuhi kebutuhan masyarakat berupa kredit (Taswan 2010). Analisis risiko likuiditas ini dimaksudkan untuk mengukur seberapa besar kemampuan bank tersebut mampu membayar utang-utangnya dan membayar kembali kepada deposannya serta dapat memenuhi permintaan kredit yang diajukan tanpa terjadi penangguhan (Merkusiwati, 2007). Kredit yang diberikan tidak termasuk kredit kepada bank lain sedangkan untuk dana pihak ketiga adalah giro, tabungan, simpanan berjangka, sertifikat deposito (Dewi, 2010). Rasio ini dirumuskan sebagai berikut:

$$
\text { LDR }=\frac{\text { Total Kredit }}{\text { Total Dana Pihak Ketiga }} \quad x 100 \%
$$

Sumber: Bank Indonesia

2. Good Corporate Governance (GCG)

Penilaian faktor GCG merupakan penilaian terhadap kualitas manajemen Bank atas pelaksanaan prinsip-prinsip GCG. Prinsip-prinsip GCG dan fokus penilaian terhadap pelaksanaan prinsip-prinsip GCG berpedoman pada ketentuan Bank Indonesia mengenai Pelaksanaan GCG bagi Bank Umum dengan memperhatikan karakteristik dan kompleksitas usaha Bank. Menurut Lesmana (2008) penilaian kualitas manajemen suatu bank dapat dilakukan dengan menghitung rasio-rasio efesiensi usaha. Melalui rasio-rasio efesiensi usaha, tingkat efesiensi yang telah dicapai oleh manajemen bank yang bersangkutan dapat diukur secara kuantitatif. Pada indikator ini diukur dengan rasio Biaya Operasional terhadap Pendapatan Operasional (BOPO) karena menurut beberapa penelitian yang telah dilakukan sebelumnya BOPO memiliki pengaruh yang signifikan terhadap GCG (Santoso, 2012; Purnamasari, 2012; Pratiwi 2013).

Menurut Surat Edaran BI No. 3/30DPNP tanggal 14 Desember 2001, BOPO diukur dari perbandingan antara biaya operasional terhadap pendapatan operasioanal. Biaya operasi merupakan biaya yang dikeluarkan oleh bank dalam rangka menjalankan aktivitas usaha pokoknya (biaya bunga, biaya tenaga kerja, biaya pemasaran, dan biaya operasi lainnya). Pendapatan operasi merupakan pendapatan utama bank yaitu pendapatan bunga yang diperoleh dari penempatan dana dalam bentuk kredit dan pendapatan operasi lainnya. Semakin kecil rasio ini berarti semakin efesien biaya operasional yang dikeluarkan bank yang bersangkutan sehingga kemungkinan suatu bank dalam kondisi bermasalah semakin kecil. Rasio BOPO dirumuskan sebagai berikut:

$$
\mathrm{BOPO}=\frac{\text { Biaya Operasional }}{\text { Pendapatan Operasional }} \times 100 \%
$$

Sumber: Bank Indonesia 
JURNAL

MANAJEMEN

INDONESIA

Vol. 15 - No. 1

April 2015
3. Rentabilitas (Earning)

Penilaian faktor Rentabilitas meliputi evaluasi terhadap kinerja Rentabilitas, sumber-sumber Rentabilitas, kesinambungan (sustainability) Rentabilitas, dan manajemen Rentabilitas. Pada prinsipnya Rentabilitas digunakan untuk mengetahui kemampuan bank dapat menghasilkan pendapatan. Penilaian earning dimaksudkan untuk mengevaluasi kondisi dan kemampuan rentabilitas bank dalam mendukung kegiatan operasional dan permodalan. Pada indikator ini diukur dengan rasio Return On Asset (ROA) dan Net Interest Margin (NIM).

Rasio ROA digunakan untuk mengukur kemampuan perusahaan menghasilkan laba dengan menggunakan total aset (kekayaan) yang dimiliki perusahaan setelah disesuaikan dengan biaya-biaya untuk mendanai aset tersebut. Total aset yang umum digunakan untuk mengukur ROA sebuah bank adalah jumlah dari aset-aset produktif yang terdiri dari penempatan surat-surat berharga dan penempatan dalam bentuk kredit. Semakin tinggi ROA akan semakin baik, karena untuk memperoleh ROA yang besar diperlukan adanya aktiva produktif yang berkualitas dan manajemen yang solid. Selain itu, semakin tinggi ROA, semakin besar pula tingkat keuntungan yang dicapai bank sehingga kemungkinan suatu bank dalam kondisi bermasalah semakin kecil (Dewi, 2010) . Rasio ini dirumuskan sebagai berikut:

$$
\begin{aligned}
& \text { Return On Asset }(R O A)=\frac{\text { Laba Sebelum Pajak }}{\text { Rata }- \text { rata Total Aset }} \quad \text { x 100\% } \\
& \text { Sumber: Bank Indonesia }
\end{aligned}
$$

Rasio NIM digunakan untuk mengukur kemampuan bank menghasilkan pendapatan bunga bersih dengan penempatan aktiva produktif yang dimiliki perusahaan (Taswan, 2010). Pendapatan bunga bersih diperoleh dari pendapatan bunga dikurangi beban bunga. Semakin besar rasio ini maka meningkatnya pendapatan bunga atas aktiva produktif yang dikelola bank sehingga kemungkinan suatu bank dalam kondisi bermasalah semakin kecil (Dewi, 2010). Rasio ini dirumuskan sebagai berikut:

Net Interest Margin (NIM) $=\frac{\text { Pendapatan Bunga Bersih }}{\text { Rata }- \text { rata Aktiva Produktif }} \times 100 \%$

Sumber: Bank Indonesia

\section{Permodal (Capital)}

Penilaian atas faktor Permodalan meliputi evaluasi terhadap kecukupan Permodalan dan kecukupan pengelolaan Permodalan. Dalam melakukan perhitungan Permodalan, Bank wajib mengacu pada ketentuan Bank Indonesia yang mengatur mengenai Kewajiban Penyediaan Modal Minimum bagi Bank Umum. Selain itu, dalam melakukan penilaian kecukupan Permodalan, Bank juga harus mengaitkan kecukupan modal dengan Profil Risiko Bank. Semakin tinggi Risiko Bank, semakin besar modal yang harus disediakan untuk mengantisipasi Risiko tersebut. Permodalan merupakan faktor yang sangat penting bagi perkembangan dan kemajuan bank serta upaya untuk tetap menjaga kepercayaan masyarakat. Pada indikator ini diukur dengan rasio kecukupan modal (Capital Adequacy Ratio/CAR). 
Rasio CAR berkaitan dengan penyediaan modal sendiri yang diperlukan untuk menutup risiko kerugian yang mungkin timbul dari penanaman dana dalam aktiva-aktiva produktif yang mengandung risiko, serta untuk pembiayaan penanaman dalam aktiva tetap dan investasi. Semakin besar rasio ini maka kesehatan bank akan semakin membaik karena hal ini berarti modal yang dimiliki bank mampu menutupi risiko kerugian yang timbul dari penanaman dana dalam aktiva-aktiva produktif yang mengandung risiko, serta dapat digunakan untuk pembiayaan penanaman dalam aktiva tetap dan investasi. Rasio ini dapat dirumuskan sebagai berikut:

$$
\begin{aligned}
& \text { Capital Adequacy Ratio }(\mathrm{CAR})=\frac{\text { Modal Bank }}{\text { Total TMR }} \times 100 \% \\
& \text { Sumber: Bank Indonesia }
\end{aligned}
$$

\subsection{Kerangka pemikiran}

Menurut Dewi (2012) kinerja perusahaan yang baik direpresentasikan dari laporan keuangan yang baik, yang sangat berpengaruh terhadap peringkat obligasi yang diberikan oleh lembaga pemeringkat obligasi. Pada penelitian ini menggunakan rasio-rasio RBBR yang didalamnya terdapat indikator-indikator seperti Profil Risiko, GCG, Rentabilitas, dan Permodalan kemudian masing-masing indikator tersebut diproksikan dengan rasio keuangan. Beberapa proksi tersebut diadopsi dari penelitian terdahulu yang diperkuat dengan teori-teori pendukung. Melalui kerangka pemikiran pada gambar 2.2 berikut ini dapat terlihat lebih jelas variabel - variabel yang digunakan dalam penelitian ini.

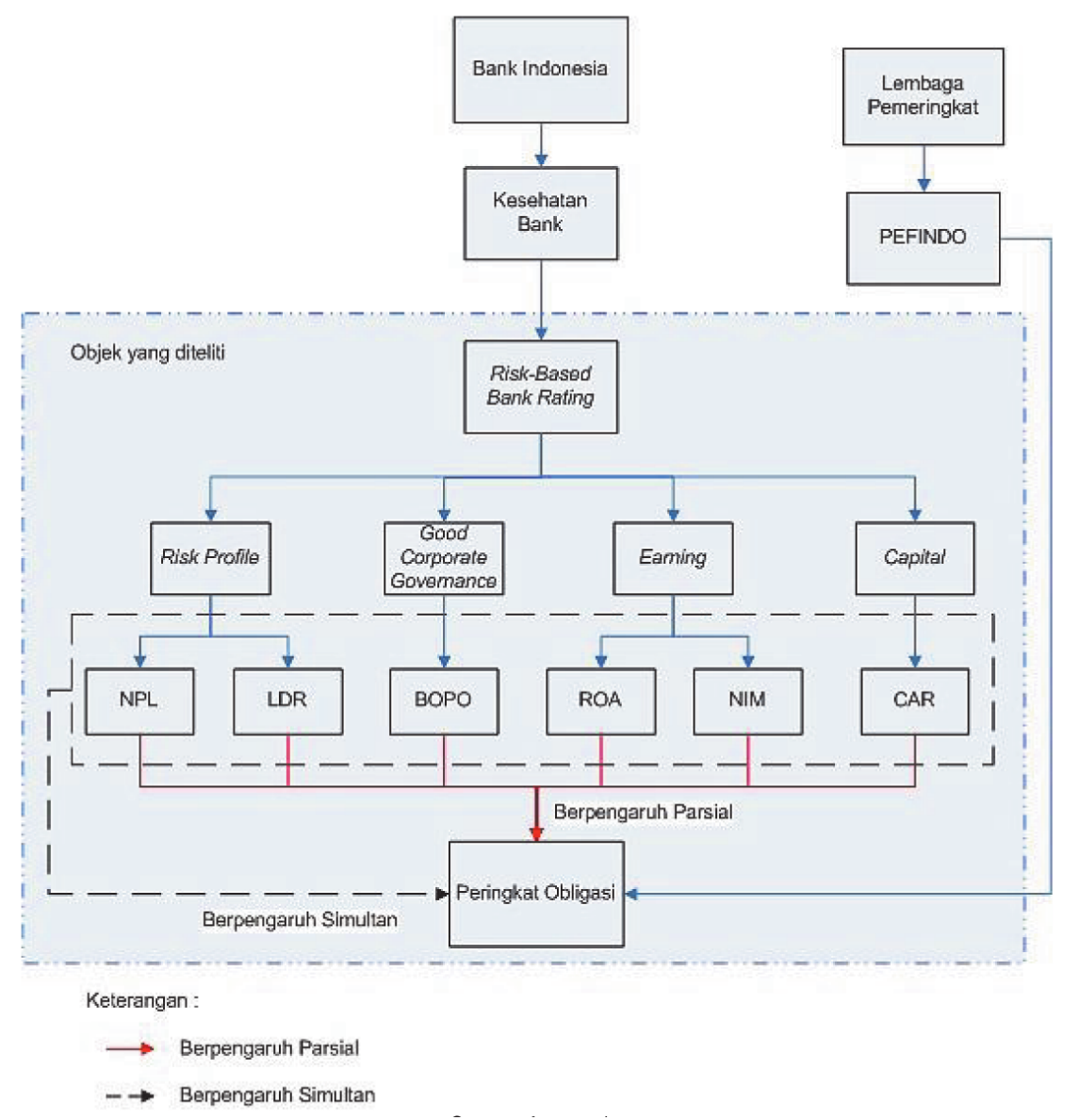

Gambar 1.

Kerangka

Pemikiran 


\subsection{Ruang lingkup penelilian}

Didalam penelitian ini dibahas ruang lingkup penelitian adalah sebagai

JURNAL

MANAJEMEN

INDONESIA

Vol. 15 - No. 1

April 2015 berikut:

1. Data laporan keuangan yang digunakan terbatas pada data keuangan per tahun 2009-2013 yang telah diaudit.

2. Rating obligasi yang digunakan adalah rating obligasi per akhir tahun.

3. Penelitian hanya mengacu pada laporan keuangan dan hanya meneliti secara kuantitatif berdasarkan rasio-rasio keuangan, sedangkan pengukuran GCG menggunakan rasio BOPO.

4. Penelitian ini tidak meneliti faktor non-akuntansi seperti jaminan obligasi, maturity, reputasi auditor dan sebagainya.

5. Objek penelitian ini terbatas pada surat utang berupa obligasi korporasi perbankan yang diperingkatkan oleh PEFINDO

6. Penelitian ini dimulai dari September 2013 sampai dengan Januari 2014

\section{METODE PENELITIAN}

\subsection{Populasi dan Sampel}

Populasi dalam penelitian ini adalah obligasi korporasi konvensional sektor perbankan yang terdaftar di Bursa Efek Indonesia dan diperingkatkan oleh PEFINDO pada tahun 2009 hingga 2013 yaitu sebanyak 38 bank. Dalam penelitian ini teknik pengambilan sampel yang digunakan adalah teknik purposive sampling yaitu pemilihan sampel dengan bertujuan dengan kriteria berupa pertimbangan tertentu dan menghasilkan 8 Bank yang dijadikan sampel penelitian. Data yang digunakan dalam penelitian ini adalah data sekunder. Data-data yang digunakan berupa data peringkat obligasi korporasi tahun 2009-2013 yang diperoleh dari website new.pefindo.com dan laporan keuangan perusahaan perbankan tahun 2009-2013 yang diperoleh dari website www.idx.co.id.

\subsection{Variabel Operasional}

Variabel dalam penelitian ini terbagi menjadi dua yaitu variabel dependen dan variabel independen. Variabel dependen dalam penelitian ini adalah peringkat obligasi sedangkan variabel independen meliputi NPL, LDR, BOPO. ROA, NIM, dan CAR dengan skala rasio. Variabel dependen dapat dilihat berdasarkan peringkat yang dikeluarkan oleh PEFINDO yang dikonversikan menjadi skala angka pada peringkat obligasi dengan skala tertinggi untuk perusahaan yang memiliki rating tertinggi dan skala yang terendah untuk perusahaan-perusahaan dengan rating yang lebih rendah, dengan asumsi jarak antar rating sama. Berikut ini adalah hasil konversi peringkat obligasi kedalam bentuk angka.

Tabel 1.

\begin{tabular}{|c|c|}
\hline PERINGKAT & KONVERSI \\
\hline AAA & 10 \\
\hline AA+ & 9 \\
\hline AA & 8 \\
\hline AA- & 7 \\
\hline A+ & 6 \\
\hline A & 5 \\
\hline A- & 4 \\
\hline BBB+ & 3 \\
\hline BBB & 2 \\
\hline BBB- & 1 \\
\hline
\end{tabular}




\subsection{Teknik Analisis Data dan Pengujian Hipotesis}

Untuk pengolah data menggunakan alat bantu berupa perangkat lunak statistik yang dikenal dengan eviews. Sedangkan teknik analisis yang digunakan meliputi : statistik deskriptif, analisis regresi dan uji hipotesis.

\subsubsection{Statistik Deskriptif}

Statistik deskriptif adalah statistik yang digunakan untuk menganalisis data dengan cara mendeskripsikan atau menggambarkan data yang telah terkumpul sebagimana adanya tanpa bermaksud membuat kesimpulan yang berlaku untuk umum atau generalisasi (Sugiyono, 2011:29). Uji statistik deskriptif mencakup nilai minimum, nilai maksimum dan nilai rata-rata (mean).

\subsubsection{Analisis Regresi}

Dalam penelitian ini regresi dilakukan dengan pemodelan data panel. Model data panel adalah penggabungan data cross section dan time series sehingga memiliki dimensi ruang dan waktu sekaligus. Menurut Nachrowi (2006) penggunaan data panel memberikan beberapa keuntungan sebagai berikut:

1. Mampumengontrol heterogenitas.

2. Memberikan lebih banyak informasi, lebih bervariasi, mengurangi kolinearitas antar variabel, meningkatkan degrees of freedom dan lebih efisien.

3. Lebih baik untuk study of dynamic adjustment.

4. Mampu mengidentifikasi dan mengukur data secara sederhana yang tidak dapat diperoleh dari data cross section murni dan data time series murni.

5. Dapat menguji dan membangun model perilaku yang lebih kompleks.

Berdasarkan keunggulan-keunggulan tersebut, data panel memiliki implikasi bahwa tidak harus dilakukan pengujian asumsi klasik dalam mode data panel (Verbeek, 2000; Gujarati, 2003; Wibisono, 2005; Aulia, 2004: 27, dalam Ajija et al., 2011).

\subsubsection{Pengujian Hipotesis}

Setelah melakukan regresi antara variabel independen dengan variabel dependen dan model telah memenuhi asumsi klasik sebagaimana dijelaskan pada bagian sebelumnya, maka langkah berikutnya dapat dilakukan uji $R^{2}, F, t$. Berikut ini penjelasan dari masingmasing pengujian:

\section{1. $\quad U j i R^{2}$ (Koefisien Determinasi)}

Nilai $R^{2}$ menunjukkan seberapa besar kemampuan model yaitu kemampuan dari variabel independen menjelaskan keragaman dari variabel dependen. Dengan melihat angka $R^{2}$ kita dapat seberapa baik model regresi. Nilai $R^{2}$ berkisar antara 0 $<R^{2}<100 \%$. Semakin besar nilai $R^{2}$ (mendekati $100 \%$ ), maka semakin baik model regresi tersebut.

\section{Uji F (Uji Signifikansi Simultan)}

Uji $\mathrm{F}$ dilakukan untuk melihat bagaimana pengaruh dari variabel independen secara bersamaan (sekaligus) terhadap variabel independen. Untuk mengetahui hipotesis ini diterima 
JURNAL

MANAJEMEN

INDONESIA

Vol. 15 - No. 1

April 2015 atau ditolak yaitu dengan melihat tingkat signifikasinya. Nilai $F$ tabel diperoleh dengan tingkat signifikasi $5 \%(\alpha=0,05)$. Apabila $F$ hitung $>F_{\text {tabel }}$ dan prob. $($ F statistic $)<0.05$, maka variabel signifikan atau $\mathrm{H}_{1}$ diterima begitu pula sebaliknya

\section{Ujit (Uji Signifikansi Parsial)}

Uji t dapat dipakai untuk melihat signifikansi variabel independen secara individual terhadap variabel dependen dengan menganggap variabel independen yang lain bersifat konstan. Untuk mengetahui hipotesis ini diterima atau ditolak yaitu dengan melihat tingkat signifikasinya. Nilai $t_{\text {tabel }}$ diperoleh dengan tingkat signifikasi $5 \%(\alpha=0,05)$, kemudian $t_{\text {tabel }}$ dicari dengan ketentuan $\mathrm{db}=\mathrm{n}-1$.

\section{HASILDAN PEMBAHASAN}

\subsection{Statistik Deskriptif}

Penelitian ini menggunakan statistik deskriptif untuk mengetahui nilai minimum, maksimum, dan rata-rata dari keseluruhan data mengenai rasiorasio yang berpengaruh terhadap peringkat obligasi. Berikut ini merupakan output dari eviews tersaji pada tabel 2.

Tabel 2.

Statistik Deskriptif

Sumber :

Olah Data Sekunder, 2014

\begin{tabular}{|l|cccccc|}
\hline \multicolumn{1}{|c}{} & NPL & LDR & BOPO & ROA & NIM & CAR \\
\hline Mean & 0.034053 & 0.812049 & 0.802283 & 0.022441 & 0.058506 & 0.166013 \\
Median & 0.030112 & 0.817366 & 0.786669 & 0.023539 & 0.049847 & 0.167521 \\
Maximum & 0.062515 & 1.015263 & 1.135312 & 0.049618 & 0.106130 & 0.229030 \\
Minimum & 0.007206 & 0.612681 & 0.624176 & -0.017124 & 0.035454 & 0.115466 \\
\hline
\end{tabular}

Berdasarkan tabel 2 nilai minimun pada masing-masing rasio yang secara berurutan beserta bank yang bersangkutan adalah (1) NPL dengan nilai 0,007206 atau 0,72\% diperoleh dari Bank OCBC NISP tahun 2013, (2) LDR dengan nilai 0,612681 atau 61,26\% diperoleh dari Bank Mandiri tahun 2009, (3) BOPO dengan nilai 0,624176 atau 62,42\% diperoleh dari Bank Rakyat Indonesia Tahun 2013, (4) ROA dengan nilai -0,017124 atau -1,71\% diperoleh dari Bank ICB Bumiputera tahun 2012, (5) NIM dengan nilai 0,035454 atau 3,54\% diperoleh dari Bank Permata tahun 2013, dan (6) CAR dengan nilai 0,115466 atau 11,55\% diperoleh dari Bank ICB Bumiputera tahun 2010. Sedangkan nilai Maksimum pada masing-masing rasio yang secara berurutan beserta bank yang bersangkutan adalah (1) NPL dengan nilai 0,062515 atau 6,25\% diperoleh dari Bank ICB Bumiputera tahun 2012, (2) LDR dengan nilai 1,015263 atau 101,53\% diperoleh dari Bank Danamon tahun 2013, (3) BOPO dengan nilai 1,135312 atau 113,53\% diperoleh dari Bank ICB Bumiputera Tahun 2012, (4) ROA dengan nilai 0,049618 atau 4,96\% diperoleh dari Bank Rakyat Indonesia tahun 2012, (5) NIM dengan nilai 0,106130 atau 10,61\% diperoleh dari Bank Danamon tahun 2010, dan (6) CAR dengan nilai 0,229030 atau 22,90\% diperoleh dari Bank Panin tahun 2009. 


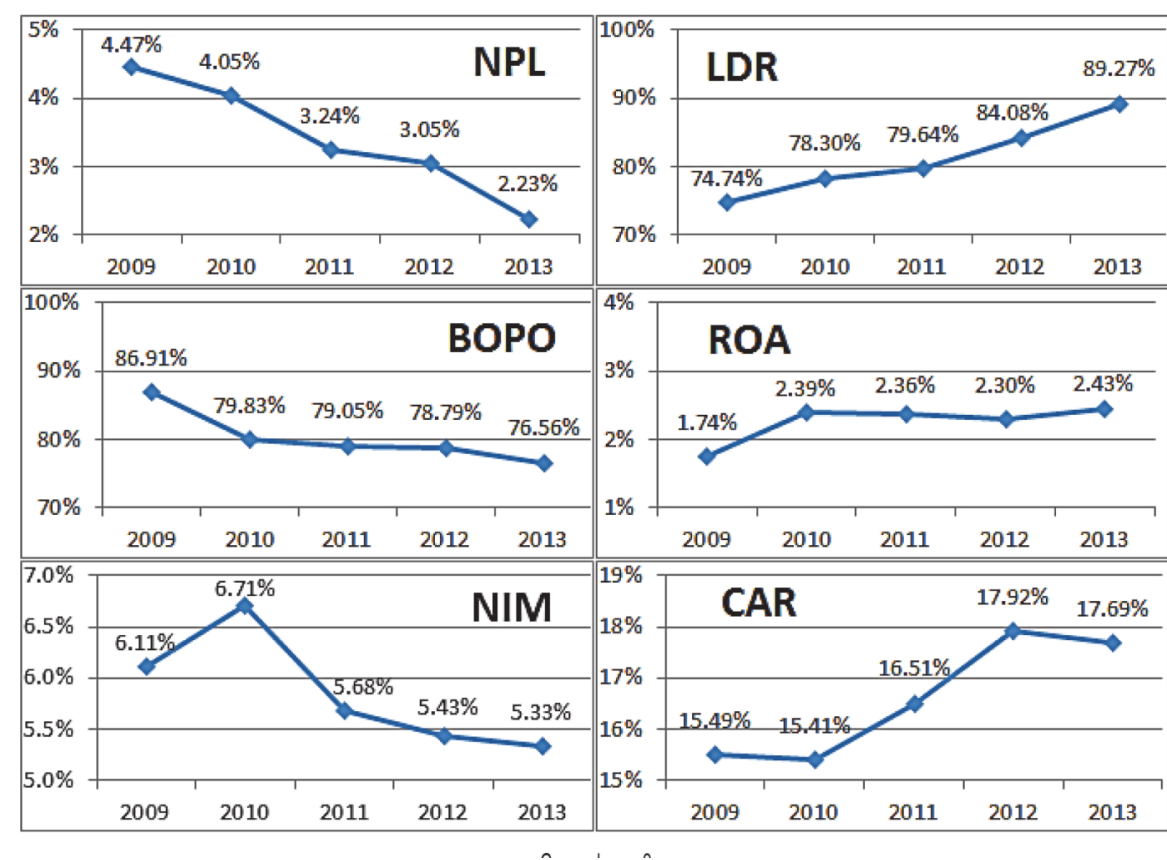

Pada gambar 2 menggambarkan bagaimana perkembangan rasio NPL, LDR, BOPO, ROA, NIM, dan CAR melalui rata-rata masing-masing rasio pada setiap tahunnya. Secara keseluruhan masing-masing rasio menunjukkan perkembangan yang relatif baik. Seperti rasio NPL menunjukkan penurunan nilai berturut-turut dari 2009 sebesar 4,47\% hingga tahun 2013 sebesar $2,23 \%$. Hal ini menunjukkan setiap tahun rasio NPL mengalami kinerja yang baik karena semakin kecil rasio NPL, jumlah kredit bermasalah yang ditanggung bank semakin berkurang.

Selain itu rasio LDR juga menunjukkan perkembangan yang baik karena setiap tahunnya berturut-turut nilainya meningkat dari tahun 2009 sebesar $74,74 \%$ hingga tahun 2013 nilai rasionya sebesar $89,27 \%$. Hal ini menunjukan semakin besar nilai LDR, semakin baik kemampuan bank untuk memenuhi kemungkinan ditariknya simpanan dana oleh nasabah begitu pula memenuhi kebutuhan masyarakat dalam memberikan kredit.

Selanjutnya rasio BOPO megalami perkembangan yang baik karena pada tahun 2009 nilainya menurun sebesar 86,91\% hingga tahun 2013 sebesar $75,56 \%$. Hal ini menunjukkan bahwa semakin kecil nilai rasio BOPO semakin efisien pengelolaan biaya operasional yang digunakan bank. Sedangkan ROA memiliki perkembangan relatif baik yaitu peningkatan dari tahun 2009 sebesar 1,74\% hingga tahun 2013 sebesar 2,43\%, namun pada tahun 2011 dan 2012 mengalami sedikit penurunan namun tidak signifikan. Peningkatan ini menandakan keuntungan yang dihasilkan bank setiap tahunnya terus meningkat. Kemudian rasio CAR juga mengalami peningkatan relatif sepanjang tahun 2009 dengan nilai 15,49\% hingga tahun 2013 dengan nilai 17,69\%. Namun tahun 2010 dan 2013 mengalami sedikit penurunan tetapi tidak seignifikan. Dengan meningkatnya nilai CAR, maka semakin besar cadangan penyediaan modal sendiri yang digunakan untuk menutup risiko kerugian. Berlainan dengan rasio NIM mengalami perkembangan kurang baik karena nilainya dari tahun 2009 menurun sebesar 6,11\% hingga tahun 2013 sebesar 5,33\%, walaupun pada tahun 2010 meningkat hingga 6,71\%. Hal ini menunjukkan bahwa kemampuan bank dalam menghasilkan pendapatan bunga meningkat namun tidak sebanding dengan peningkatan jumlah aktiva produktif sehingga bank dianggap kurang mampu mengelola aktiva produktif untuk menghasilkan lebih banyak keuntungan.
JURNAL

MANAJEMEN

INDONESIA

Vol. 15 - No. 1

April 2015

\section{Gambar 2.}

Perkembangan Rasio RBBR

Tahun 2009-2013

Sumber :

Olah data sekunder, 2014 


\subsection{Analisis Regresi Data Panel}

Penelitian ini menggunakan teknik analisis regresi data panel. Data

JURNAL

MANAJEMEN

INDONESIA

Vol. 15 - No. 1

April 2015
Tabel 3.

Uji Chow

Sumber:

Olah Data Sekunder,

2014 panel merupakan gabungan antara data cross section (banyak perusahaan) dan data time series (banyak waktu). Dimana dalam analisis regresi data panel memiliki tiga model yaitu model common effect, fixed effect, dan random effect.

\subsubsection{Pengujian Model}

Untuk mengetahui model yang sesuai untuk digunakan dalam penelitian maka perlu dilakukan pengujian model. Langkah pertama yang dilakukan adalah menguji model common effect atau fixed effect dengan menggunakan uji Chow. Selanjutnya ketika hasil uji menyatakan lebih baik menggunakan fix effect maka dilakukan langkah kedua yaitu dengan uji Hausman. Uji Hausman digunakan untuk menguji lebih baik model fixed effect atau random effect. Berikut ini pengujian model sekaligus dengan penjelasan dari pemilihan model:

\section{A. UjiChow}

Dalam uji Chow dapat dihitung melalui eviews dengan menggunakan menu likelihood ratio. Uji Chow menggunakan Likelihood Ratio pada alat uji statistik untuk memilih antara model Common Effect dan model Fixed Effect, dengan ketentuan pengambilan keputusan sebagai berikut:

$\mathrm{H}_{0}$ : Model Common Effect

$\mathrm{H}_{1}$ : Model Fixed Effect

Jika nilai prob.( $p$-value) cross section Chi-square $<0.05$ (taraf signifikansi $=5 \%$ ) atau nilai prob. $(p$-value) cross section $\mathrm{F}<$ 0.05 maka $\mathrm{H}_{0}$ ditolak atau regresi data panel tidak menggunakan model Common Effect. Namun, jika nilai prob.( $p$-value) cross section Chi-square $>0.05$ (taraf signifikansi $=5 \%$ ) atau nilai prob.( $p$-value) cross section $\mathrm{F}>0.05$ maka $\mathrm{H}_{0}$ diterima atau regresi data panel menggunakan model Common Effect. Berdasarkan pengujian Fixed Effect, maka diperoleh data hasil pengujian sebagai berikut :

Berdasarkan hasil uji tersebut diperoleh nilai prob. crosssection Chi-square sebesar 0,0000 lebih kecil dari taraf signifikansi $5 \%$ dan nilai prob. cross-section $\mathrm{F}$ sebesar 0,0000 lebih kecil dari taraf signifikansi 5\%, menunjukkan bahwa nilai prob.( $p$-value) < 0,05 maka sesuai dengan ketentuan pengambilan keputusan bahwa $\mathrm{H}_{0}$ ditolak atau penelitian ini tidak menggunakan model Common Effect. Selanjutnya, dilakukan pengujian antara model Fixed Effect dengan model Random Effect dengan menggunakan Hausman Test.

Redundant Fixed Effects Tests

Equation: Untitled

Test cross-section fixed effects

\begin{tabular}{lcrr}
\hline \hline Effects Test & Statistic & d.f. & Prob. \\
\hline \hline Cross-section F & 10.285354 & $(7,26)$ & 0.0000 \\
Cross-section Chi-square & 53.073807 & 7 & 0.0000 \\
\hline \hline
\end{tabular}


B. Uji Hausman

Setelah dilakuakan uji Chow dan menerima $H_{1}$ yaitu menggukan model fixed effect maka perlu dilanjutkan dengan uji Hausman untuk menentukan apakah nantinya akan menggunakan model Fixed Effect atau model Random effect dalam proses regresi data panel pada penelitian ini, dengan ketentuan pengambilan keputusan sebagai berikut:

$\mathrm{H}_{0}$ : Model Random Effect

$\mathrm{H}_{1}$ : Model Fixed Effect

Jika nilai statistik Hausman (Chi-square Statistic) > nilai kritisnya (Chi-square 5\%, df) atau nilai prob.(p-value) cross section random $<0,05$ maka $\mathrm{H}_{0}$ ditolak atau regresi data panel tidak menggunakan model Random effect. Namun, jika nilai statistik Hausman (Chi-square Statistic) < nilai kritisnya (Chisquare $5 \%$, df) atau nilai prob.(p-value) cross section random $>$ 0,05 maka $\mathrm{H}_{0}$ diterima atau regresi data panel menggunakan model Random effect. Berdasarkan pengujian Random effect (Hausman Test), maka diperoleh data hasil pengujian sebagai berikut:

Correlated Random Effects - Hausman Test

Equation: Untitled

Test cross-section random effects

\begin{tabular}{lccc}
\hline \hline \multirow{2}{*}{ Test Summary } & $\begin{array}{c}\text { Chi-Sq. } \\
\text { Statistic }\end{array}$ & Chi-Sq. d.f. & Prob. \\
\hline \hline Cross-section random & 71.633789 & & 0.0000 \\
\hline \hline
\end{tabular}

Tabel 4.

Uji Hausman

Sumber:

Olah Data Sekunder, 2014

Berdasarkan hasil uji Random effect nilai prob.crosssection random ( $p$-value) sebesar $0.0000<0,05$, maka sesuai dengan ketentuan pengambilan keputusan bahwa $\mathrm{H}_{1}$ diterima yaitu regresi data panel menggunakan model fixed effect. Maka model yang digunakan pada penelitian kelompok ini adalah model Fixed effect.

\subsubsection{Persamaan Regresi Data Panel}

Berdasarkan pengujian model yang dilakukan, maka model yang digunakan dalam regresi data panel pada penelitian ini adalah model fixed Effect. Dengan menggunakan eviews 7 maka dihasilkan output seperti pada Tabel 5 yang merupakan hasil uji dengan model fixed Effect. 
JURNAL

MANAJEMEN

INDONESIA

Vol. 15 - No. 1

April 2015

Tabel 5.

Model Fixed Effect

Sumber:

Olah Data Sekunder, 2014
Dependent Variable: PERINGKAT_OBLIGASI

Method: Panel Least Squares

Date: 01/01/14 Time: 16:53

Sample: 20092013

Periods included: 5

Cross-sections included: 8

Total panel (balanced) observations: 40

\begin{tabular}{crrrr}
\hline \hline Variable & Coefficient & Std. Error & t-Statistic & Prob. \\
\hline \hline C & 17.06580 & 7.344913 & 2.323485 & 0.0282 \\
NPL & -25.90367 & 12.59839 & -2.056110 & 0.0499 \\
LDR & 1.354128 & 1.802543 & 0.751232 & 0.4593 \\
BOPO & -6.455914 & 7.797771 & -0.827918 & 0.4153 \\
ROA & -47.51901 & 72.10592 & -0.659017 & 0.5157 \\
NIM & -24.48251 & 17.68380 & -1.384460 & 0.1780 \\
CAR & -9.969728 & 6.030488 & -1.653221 & 0.1103 \\
\hline \hline
\end{tabular}

Effects Specification :

\begin{tabular}{lrll}
\hline \hline Cross-section fixed (dummy variables) & \\
\hline \hline R-squared & 0.955701 & Mean dependent var & 7.950000 \\
Adjusted R-squared & 0.933552 & S.D. dependent var & 2.352849 \\
S.E. of regression & 0.606507 & Akaike info criterion & 2.107018 \\
Sum squared resid & 9.564133 & Schwarz criterion & 2.698125 \\
Log likelihood & -28.14035 & Hannan-Quinn criter. & 2.320744 \\
F-statistic & 43.14784 & Durbin-Watson stat & 1.982880 \\
Prob(F-statistic) & 0.000000 & & \\
\hline
\end{tabular}

Model persamaan regresi data panel yang dibentuk dalam penelitian ini merupakan model fixed Effect. Berdasarkan tabel 5 dapat diketahui nilai konstanta koefisien sehingga dapat dibentuk dalam persamaan regresi data panel sebagai berikut :

PERINGKAT_OBLIGASI $=17.0657987008-25.9036713662 * N P L+$ 1.35412824852*LDR -6.45591371637*BOPO - 47.5190096121*ROA 24.4825105824*NIM - 9.96972845972*CAR

Persamaan diatas dapat diartikan sebagai berikut :

1. Koefisien intersep bernilai positif sebesar 17.0657987008 yang berarti apabila rasio NPL, LDR, BOPO, ROA, NIM, dan CAR konstan (tidak mengalami perubahan) maka Peringkat obligasi akan bernilai sebesar 17.0657987008 .

2. Koefisien rasio NPL memiliki arah hubungan negatif sebesar 25.9036713662. Dengan asumsi setiap kenaikan rasio NPL sebesar $1 \%$ akan menyebabkan penurunan pada peringkat obligasi sebesar $25.90 \%$, begitu pula penurunan rasio NPL sebesar $1 \%$ akan menyebabkan kenaikan pada peringkat obligasi sebesar $25.90 \%$.

3. Koefisien rasio LDR memiliki arah hubungan positif sebesar 1.35412824852. Dengan asumsi setiap kenaikan rasio LDR sebesar $1 \%$ akan menyebabkan kenaikan pada peringkat obligasi sebesar $1.35 \%$, begitu pula penurunan rasio LDR sebesar $1 \%$ akan menyebabkan penurunan pada peringkat obligasi sebesar $1.35 \%$. 
4. Koefisien rasio BOPO memiliki arah hubungan negatif sebesar 6.45591371637. Dengan asumsi setiap kenaikan rasio BOPO sebesar $1 \%$ akan menyebabkan penurunan pada peringkat obligasi sebesar $6.45 \%$, begitu pula penurunan rasio BOPO sebesar $1 \%$ akan menyebabkan kenaikan pada peringkat obligasi sebesar $6.45 \%$.

5. Koefisien rasio ROA memiliki arah hubungan negatif sebesar 47.5190096121. Dengan asumsi setiap kenaikan rasio ROA sebesar $1 \%$ akan menyebabkan penurunan pada peringkat obligasi sebesar $47.51 \%$, begitu pula penurunan rasio ROA sebesar $1 \%$ akan menyebabkan kenaikan pada peringkat obligasi sebesar $47.51 \%$.

6. Koefisien rasio NIM memiliki arah hubungan negatif sebesar 24.4825105824. Dengan asumsi setiap kenaikan rasio NIM sebesar $1 \%$ akan menyebabkan penurunan pada peringkat obligasi sebesar $24.48 \%$, begitu pula penurunan rasio NIM sebesar $1 \%$ akan menyebabkan kenaikan pada peringkat obligasi sebesar $24.48 \%$.

7. Koefisien rasio CAR memiliki arah hubungan negatif sebesar 9.96972845972. Dengan asumsi setiap kenaikan rasio CAR sebesar $1 \%$ akan menyebabkan penurunan pada peringkat obligasi sebesar $9.96 \%$, begitu pula penurunan rasio CAR sebesar $1 \%$ akan menyebabkan kenaikan pada peringkat obligasi sebesar $9.96 \%$.

\subsubsection{Koefisien Determinasi $\left(R^{2}\right)$}

Uji ketepatan perkiraan model (goodness of fit) dilakukan untuk melihat kesesuaian model. Secara statistik, dapat diukur dari nilai koefisien korelasi, nilai statistik F, dan nilai statistik t (Ghozalli, 2011: 97). Koefisien determinasi $\left(R^{2}\right)$ digunakan untuk mengukur seberapa jauh kemampuan model dalam menerangkan variasi variabel independen. Nilai koefisien determinasi yang mendekati satu berarti variabelvariabel independen hampir memberikan semua informasi yang dibutuhkan untuk memprediksi variabel dependen. Berdasarkan tabel 5, diperoleh bahwa nilai $\mathrm{R}^{2}$ ( $R$-square) sebesar 0.955701 atau $95,57 \%$. $\mathrm{Hal}$ ini mengindikasikan bahwa variabel independen yang terdiri dari rasio NPL, LDR, BOPO, ROA, NIM, dan CAR mampu menjelaskan variabel dependen yaitu peringkat obligasi sebesar $95,57 \%$. sedangkan sisanya $4,43 \%$ dijelaskan oleh variabel lain di luar penelitian.

\subsubsection{Uji F (Simultan)}

Uji $F$ (simultan) dilakukan untuk menguji apakah variabel independen secara simultan atau bersama-sama memiliki pengaruh signifikan terhadap variabel dependen. Dengan ketentuan pengambilan keputusan, apabila nilai prob (F statistic) $<0.05$ (taraf signifikansi 5\%) maka $\mathrm{H}_{0}$ ditolak yang berarti variabel independen memiliki pengaruh signifikan terhadap variabel dependen secara bersama-sama. Namun, jika nilai prob.(F-statistic) $>0,05$ (taraf signifikansi 5\%) maka $\mathrm{H}_{0}$ diterima yang berarti variabel independen tidak berpengaruh signifikan terhadap variabel dependen secara bersama-sama. 
JURNAL

MANAJEMEN

INDONESIA

Vol. 15 - No. 1

April 2015

Tabel 6.

Uji-t (Parsial)

Sumber:

Olah Data Sekunder, 2014
Berdasarkan tabel 5, diperoleh bahwa nilai prob.(F-statistic) sebesar 0,000000 < 0,05 dan F-hitung > F-tabel yaitu $43.14784>3,798$ maka $\mathrm{H}_{1 \mathrm{~A}}$ diterima yang berarti rasio NPL, LDR, BOPO, ROA, NIM, dan CAR berpengaruh terhadap peringkat secara simultan atau bersamasama.

\subsubsection{Uji T (Parsial)}

Uji-t (parsial) dilakukan untuk menentukan nilai koefisien regresi secara sendiri-sendiri terhadap variabel terikat $(Y)$ apakah signifikan atau tidak. Ketentuan pengambilan keputusan uji parsial yaitu jika $t_{\text {hitung }}>$ $t_{\text {tabel }}$ atau $-t_{\text {hitung }}<-t_{\text {tabel }}$ dan jika nilai prob. $(p$-value) $<0,05$ (taraf signifikansi $5 \%$ ) maka $\mathrm{H}_{1}$ diterima yang berarti variabel bebas memiliki pengaruh signifikan terhadap variabel terikat secara parsial. Namun jika $t_{\text {hitung }}<t_{\text {tabel }}$ atau $-t_{\text {hitung }}>-t_{\text {tabel }}$ dan jika nilai prob. $(p$-value $)>0,05$ maka $\mathrm{H}_{1}$ ditolak yang berarti variabel bebas tidak berpengaruh signifikan terhadap variabel terikat secara parsial. Pada tabel 6 menggunakan nilai $t_{\text {tabel }}$ dengan $\mathrm{df} 39(\mathrm{df}=\mathrm{n}-\mathrm{k}=40-1=39)$ adalah sebesar 2,02269, sehingga hasil dari pengujian parsial adalah sebagai berikut.

\begin{tabular}{ccccc}
\hline Variabel & t-hitung & t-tabel & Prop. & Uji hipotesis \\
\hline NPL & -2.0561 & -2.0227 & 0.0499 & diterima \\
\hline LDR & 0.7512 & 2.0227 & 0.4593 & ditolak \\
\hline BOPO & -0.8279 & -2.0227 & 0.4153 & ditolak \\
\hline ROA & -0.6590 & -2.0227 & 0.5157 & ditolak \\
\hline NIM & -1.3845 & -2.0227 & 0.1780 & ditolak \\
\hline CAR & -1.6532 & -2.0227 & 0.1103 & ditolak \\
\hline
\end{tabular}

\subsection{Pembahasan}

Dari pengujian dan analisis diketahui bahwa rasio-rasio RBBR seperti NPL, LDR, BOPO, ROA, NIM, dan CAR secara bersama-sama atau simultan berpengaruh terhadap obligasi dengan nilai prob.(F-statistic) sebesar 0,000< 0,05 sehingga menerima $\mathrm{H}_{1 \mathrm{~A}}$ dan rasio-rasio tersebut mempu menjelaskan peringkat obligasi melalui nilai $R^{2}$ ( $R$-square) sebesar 0.955701 atau $95,57 \%$ sedangkan sisanya yaitu $4,43 \%$ dijelaskan oleh variabel lain di luar penelitian.

Pada rasio NPL memiliki nilai $t_{\text {hitung }}<t_{\text {tabel }}$ yaitu $-2.0561<-2,0227$ dan memiliki nilai prob. ( $p$-value) $0.0499<0,05$ sehingga menerima $\mathrm{H}_{1 \mathrm{~B}}$ dan secara parsial rasio NPL memiliki pengaruh signifikan terhadap peringkat obligasi. Bentuk pengaruh yang ditimbulkan adalah negatif yang berarti semakin besarnya rasio NPL akan berpengaruh terhadap semakin rendahnya peringkat obligasi, begitu pula, semakin kecilnya rasio NPL akan berpengaruh pada semakin tingginya peringkat obligasi.

Pada rasio LDR memiliki nilai $t_{\text {hitung }}<t_{\text {tabel }}$ yaitu $0.7512<2,0227$ dan memiliki nilai prob. ( $p$-value) $0.4593>0,05$ sehingga menolak $\mathrm{H}_{1 \mathrm{c}}$ dan secara parsial rasio LDR tidak memiliki pengaruh signifikan terhadap peringkat obligasi. Bentuk pengaruh yang ditimbulkan adalah positif yang berarti semakin besarnya rasio LDR akan berpengaruh terhadap semakin tingginya peringkat obligasi, begitu pula, semakin kecilnya rasio LDR akan berpengaruh pada semakin rendahnya peringkat obligasi. 
Pada rasio $\mathrm{BOPO}$ memiliki nilai $\mathrm{t}_{\text {hitung }}>\mathrm{t}_{\text {tabel }}$ yaitu $-0.8279>-2,0227$ dan memiliki nilai prob. ( $p$-value) $0.4153>0,05$ sehingga menolak $\mathrm{H}_{10}$ dan secara parsial rasio BOPO tidak berpengaruh signifikan terhadap peringkat obligasi. Bentuk pengaruh yang ditimbulkan adalah negatif yang berarti semakin besarnya rasio BOPO akan berpengaruh terhadap semakin rendahnya peringkat obligasi, begitu pula, semakin kecilnya rasio BOPO akan berpengaruh pada semakin tinggin peringkat obligasi

Pada rasio ROA memiliki nilai $t_{\text {hitung }}>t_{\text {tabel }}$ yaitu $-0.6590>-2,0227$ dan memiliki nilai prob. ( $p$-value) $0.5157>0,05$, sehingga menolak $\mathrm{H}_{1 \mathrm{E}}$ dan secara parsial rasio ROA tidak memiliki pengaruh signifikan terhadap peringkat obligasi. Bentuk pengaruh yang ditimbulkan adalah negatif yang berarti semakin besarnya rasio ROA akan berpengaruh terhadap semakin rendahnya peringkat obligasi, begitu pula, semakin kecilnya rasio ROA akan berpengaruh pada semakin tingginya peringkat obligasi.

Pada rasio NIM memiliki nilai $t_{\text {hitung }}>t_{\text {tabel }}$ yaitu $-1.3844>-2,0227$ dan memiliki nilai prob. (p-value) $0.1780>0,05$, sehingga menolak $\mathrm{H}_{1 \mathrm{~F}}$ dan secara parsial rasio NIM tidak memiliki pengaruh signifikan terhadap peringkat obligasi. Bentuk pengaruh yang ditimbulkan adalah negatif yang berarti semakin besarnya rasio NIM akan berpengaruh terhadap semakin rendahnya peringkat obligasi, begitu pula, semakin kecilnya rasio NIM akan berpengaruh pada semakin tingginya peringkat obligasi.

Pada Rasio CAR memiliki nilai $t_{\text {hitung }}>t_{\text {tabel }}$ yaitu $-1.6532>-2,0227$ dan memiliki nilai prob. ( $p$-value) $0.1103>0,05$, sehingga menolak $\mathrm{H}_{16}$ dan secara parsial rasio CAR tidak memiliki pengaruh signifikan terhadap peringkat obligasi secara parsial. Bentuk pengaruh yang ditimbulkan adalah negatif yang berarti semakin besarnya rasio CAR akan berpengaruh terhadap semakin rendahnya peringkat obligasi, begitu pula, semakin kecilnya rasio CAR akan berpengaruh pada semakin tingginya peringkat obligasi.

\section{KESIMPULAN}

Tujuan dari penelitian dimaksudkan untuk menganalisis pengaruh rasio-rasio risk-based bank rating (RBBR) terhadap peringkat obligasi. Saat dilakukan penelitian melibatkan delapan bank yang terdaftar di Bursa Efek Indonesia selama 5 tahun yaitu dari tahun 2009-2013. Berdasarkan hasil pengujian dan analisis menggunakan model regresi data panel, diperoleh beberapa kesimpulan sebagai berikut:

1. Hasil penelitian menunjukkan bahwa perkembangan rasio-rasio RBBR selama tahun 2009-2013 meningkat pada rasio NPL, LDR, dan BOPO. Hasil pada rasio ROA dan CAR relatif meningkat dengan sedikit penurunan namun tidak signifikan. Sedangkan rasio BOPO mengalami penurunan yang cukup signifikan.

2. Hasil penelitian menunjukkan bahwa rasio-rasio RBBR seperti NPL, LDR, BOPO, ROA, NIM, dan CAR berpengaruh signifikan secara simultan terhadap peringkat.

3. Hasil penelitian menunjukkan bahwa NPL berpengaruh signifikan secara parsial terhadap peringkat obligasi. Dengan demikian, hasil penelitian ini tidak konsisten dengan hasil temuan Deasy (2012).

4. Hasil penelitian menunjukkan bahwa LDR tidak berpengaruh signifikan secara parsial terhadap peringkat obligasi. Dengan demikian, hasil penelitian ini konsisten dengan hasil temuan Nugraheni (2010) dan Deasy (2012). 
JURNAL

MANAJEMEN

INDONESIA

Vol. 15 - No. 1

April 2015
5. Hasil penelitian menunjukkan bahwa BOPO tidak berpengaruh signifikan secara parsial terhadap peringkat obligasi. Dengan demikian, hasil penelitian ini konsisten dengan hasil temuan Deasy (2012).

6. Hasil penelitian menunjukkan bahwa ROA tidak berpengaruh signifikan secara parsial terhadap peringkat obligasi. Dengan demikian, hasil penelitian ini konsisten dengan hasil temuan Nugraheni (2010).

7. Hasil penelitian menunjukkan bahwa NIM tidak berpengaruh signifikan secara parsial terhadap peringkat obligasi. Dengan demikian, hasil penelitian ini konsisten dengan hasil temuan Nugraheni (2010).

8. Hasil penelitian menunjukkan bahwa CAR tidak berpengaruh signifikan secara parsial terhadap peringkat obligasi. Dengan demikian, hasil penelitian ini konsisten dengan hasil temuan Deasy (2012) namun tidak konsisten dengan hasil temuan Nugraheni (2010).

\section{SARAN}

\section{a. Bagi Akademisi}

Bagi para akademisi, disarankan untuk menggunakan hasil penelitian ini sebagai tambahan informasi dan bukti empiris mengenai rasio-rasio keuangan yang tergolong pada risk-based bank rating dalam mempengaruhi peringkat obligasi serta perkembangan kinerja rasio-rasio bank selama tahun 20092013, baik untuk diterapkan dalam ilmu pengetahuan maupun dalam kehidupan sehari-hari.

\section{b. Bagi Peneliti Selanjutnya}

Berdasarkan hasil penelitian, saran yang dapat diberikan untuk penelitian sejenis berikutnya adalah sebagai berikut:

1. Penelitian selanjutnya dapat menambahkan variabel independen lain untuk mengetahui pengaruhnya terhadap peringkat obligasi karena menurut koefisien determinasi menunjukkan nilai sebesar 95,57\%. Sehingga masih terdapat 4,43\% variabel lain di luar penelitian memiliki pengaruh terhadap peringkat obligasi. Sebaiknya penelitian selanjutnya menambahkan faktor-faktor non akuntasi seperti reputasi auditor, jaminan obligasi, umur obligasi dan sebagainya dimasukkan dalam penelitian.

2. Penelitian selanjutnya dapat menggunakan proksi yang berbeda, selain dari rasio-rasio yang digunakan dalam penelitian ini. Peneliti selanjutnya dapat mencoba menggunakan rasio Return on Equity (ROE), Net Profit Margin (NPM), Risk Asset Ratio (RAR), Deposit Risk Ratio (DRR), Credit Risk Ratio (CRR), Liquidity Risk (LR), Asset to Loan Ratio (ALR), dan Quick Ratio (QR) untuk mengganti proksi pada analisis RBBR.

3. Penelitian selanjutnya diharapkan dapat menggunakan sampel lain seperti bank yang tergolong bank pembangunan daerah atau dapat mengkolaborasikan antara bank yang terdaftar di Bursa Efek Indonesia dan Bank yang tidak terdaftar di Bursa Efek Indonesia.

4. Penelitian selanjutnya dapat memperpanjang periode tahun pengamatan dengan periode atau rentang waktu yang berbeda sehingga dapat menghasilkan data yang lebih komprehensif.

\section{c. Bagi Perusahaan}

Hasil pada penelitian ini menunjukkan bahwa secara simultan rasiorasio yang digunakan dalam penelitian seperti NPL, LDR, BOPO, ROA, NIM, dan CAR berpengaruh terhadap peringkat obligasi dan secara parsial hanya NPL berpengaruh terhadap peringkat obligasi, sehingga disarankan bagi bank memperhatikan tingkat rasio-rasio tersebut untuk menjaga stabilitas atau 
meningkatkan peringkat obligasi. Selain itu manajemen bank tidak memperhatikan kinerja keuangan saja karena penilaian peringkat obligasi juga melibatkan faktor lain seperti kualitas manajemen, pelayanan, produk, dan struktur bank. Selain itu pemeringkat obligasi juga mempertimbangkan situasi pasar, persaingan bisnis dan faktor ekstenal lain dalam mementukan peringkat obligasi. Namun setidaknya dengan menjaga kesehatan perbankan dapat turut menjaga stabilitas bank menghadapi risiko gagal bayar (default) dan pembekuan aset oleh Bank Indonesia.

\section{d. Bagi Investor}

Hasil penelitian ini diharapkan dapat membantu investor dalam melakukan analisis laporan keuangan dan mempertimbangkan keputusan sebelum berinvestasi. Secara spesifik rasio-rasio keuangan seperti NPL, LDR, BOPO, ROA, NIM, dan CAR berpengaruh signifikan terhadap peringkat obligasi. Untuk itu sebelum investor memutuskan berinvestasi pada obligasi dapat melakukan analisis rasio-rasio tersebut untuk mengetahui gambaran kinerja bank dan mempelajari perkembangan naik turunnya peringkat obligasi sehingga investor dapat memutuskan berinvestasi pada suatu bank dengan tepat dan mantap.

\section{DAFTAR PUSTAKA}

Ajija, Sochrul R., Dyah W. Sari, Rahmat H. Setianto dan Martha R. Primanti. (2011). Cara Cerdas Menguasai Eviews. Jakarta: Salemba Empat

Bank Indonesia. (2004). Peraturan BI No. 6/10/PBI/2004.Tentang Sistem Penilaian Tingkat Kesehatan Bank Umum. Bank Indonesia: Jakarta

Bank Indonesia. (2011). Surat Edaran BI No. 13/24/DPNP Perihal Penilaian Tingkat Kesehatan Bank Umum. Bank Indonesia: Jakarta

Bank Indonesia. (2011). Peraturan BI No. 13/1/PBI/2011.Tentang Sistem Penilaian Tingkat Kesehatan Bank Umum. Bank Indonesia: Jakarta

Bodie, Z., Kane, A., \& Marcus, A. J. (2010). Essentials of invesments $8^{\text {th. }}$ New York: McgrawHill

Chan \& Jagedeesh. (2004). Market-Based Evaluation For Models To Predict Bond Ratings. Review Of Pacific Basin Financial Markets And Policies, Vol.7, No. 2, Hal 153-172

Dewi, Deasy Rahina Khrisna. (2012). Pengaruh Rasio-Rasio Laporan Keuangan Terhadap Peringkat Obligasi Studi Kasus Pada Perbanakan yang Mendapat Peringkat Obligasi dari PT. PEFINDO Tahun 2007-2010. IM Telkom: Bandung

Dewi, Aprilia. (2010). Rasio Keuangan Versi Bank Indonesia Versus Infobank. Universitas Diponegoro: Semarang.

Lesmana, Yuanita. (2008). Konsistensi Antara Discretionary Accrual dengan Rasio CAMEL dalam Mengukur Tingkat Kesehatan Bank. Usahawan. No.5, hal 41-47

Linandarini, Ermi. (2010). Kemampuan Rasio Keuangan Dalam Memprediksi Peringkat Obligasi Perusahaan Di Indonesia . Universitas Diponegoro:Semarang

Merkusiwati, Ni Ketut Lely Aryani. (2007). Evaluasi Pengaruh CAMEL Terhadap Kinerja Perusahaan. Buletin Studi Ekonomi, Vol. 12, No. 1

Nachrowi, Hardius Usman. (2006). Pendekatan Populer Dan Praktis Ekonometrika Untuk Analisis Ekonomi Dan Keuangan, Jakarta: Lembaga Penerbit FEUI

Pratiwi, Angrum. (2013). Analisis Kualitas Penerapan Good Corporate Governance (GCG) Serta Pengaruhnya Terhadap Kinerja Keuangan Pada Bank Umum Syariah Di Indonesia Yogyakarta: Universitas Muhammadiyah

Purnamasari, Indah. (2011). Pengaruh Good Corporate Governance Berdasarkan Corporate
JURNAL

MANAJEMEN

INDONESIA

Vol. 15 - No. 1

April 2015 
Governance Perception Index (Cgpi) Terhadap Kinerja Keuangan Perbankan Di Bursa Efek Indonesia. Jakarta: Universitas Gunadarma

JURNAL

MANAJEMEN

INDONESIA

Vol. 15 - No. 1

April 2015

Raharja. Sari, M.P. (2008). Perbandingan Alat Analisis (Diskriminan Dan Regresi Logistik Terhadap Peringkat Obligasi (PT Pefindo). Jurnal Maksi. 8 (1): 87-104

Santoso, Gesang Hadi. (2012). Pengaruh Corporate Governance Terhadap Financial Performance Perusahan. Surabaya: Universitas Negeri Surabaya

Sejati, Grace Putri. (2010). Analisis Faktor Akuntansi Dan Non Akuntansi Dalam Memprediksi Peringkat Obligasi Perusahaan Manufaktur. Bisnis \& Birokrasi, Jurnal IImu Administrasi Dan Organisasi, Jan-Apr 2010 Volume 17, Nomor 1 HIm.70-78. Issn 0854-3844

Setyapurnama, Yudi Santara., Norpratiwi, A.M. Vianey. (2008). Pengaruh Corporate Governance Terhadap Peringkat Obligasi Dan Yield Obligasi

Sugiyono. (2011). Metode Penelitian Kombinasi Bisnis (Mixed Methode). Bandung : Alfabeta.

Taswan. (2010). Manajemen Perbankan Konsep, Teknik, dan Aplikasi Edisi 2. Yogyakarta: Unit Penerbit dan Percetakan STIM YKPN.

Wilopo. (2001). Prediksi Kebangkrutan Bank. Jurnal Riset Akuntansi Indonesia, Vol.4, No.2, hal: $184-198$ 